\title{
VIRULENCE PROFILE OF BULGARIAN CLINICAL ISOLATES STREPTOCOCCUS AGALACTIAE- PCR DETERMINATION
}

\author{
Adile Muhtarova, Raina Gergova, Ivan Mitov. \\ Department of Medical Microbiology, Faculty of Medicine, Medical University \\ - Sofia, Bulgaria.
}

\begin{abstract}
Purpose: This study aims to determine the virulence profile of the circulating Bulgarian clinical isolates of GBS including the highly virulent serotype III by molecular methods and evaluate the differences among studied isolates from healthy pregnant women and non-pregnant ill persons.

Material and methods: We investigated 104 nonduplicate isolates of GBS obtained from pregnant $(n=15)$ and non-pregnant women $(\mathrm{n}=89)$, living in Sofia, Bulgaria. All GBS strains were screened for the presence of important virulence genes, namely $b c a, c y l(E), r i b, h y l(\mathrm{~B})$ and the capsular serotype III detected by Real-time PCR.

Results: PCR detection of five important virulence genes showed that $c y l E(91.3 \%)$ was the most prevalent one among the total isolates of GBS. Genes encoding the C protein $(b c a)$, hyaluronate lyase (hylB), Alp family protein Rib (rib) were presented in $51 \%, 17.3 \%$ and $22.1 \%$ respectively of the examined isolates. By using real-time PCR, we found that $13.5 \%$ from all tested Bulgarian GBS strains confirmed as GBS serotype III and harbored cpsI gene. No significant differences between the two groups were observed excluding the presence of cpsI.

Conclusion: The risk of neonatal and prenatal GBS infection in $1 / 3$ of healthy pregnant women colonized by streptococcal strains with highly virulent capsular serotype in combination with other strong virulent factors was demonstrated by this study. The regular screening for GBS and properly treatment could be reduce the severe maternal-fetal infections due to this microorganism.
\end{abstract}

Keywords: Streptococcus agalactiae, PCR, virulence factors,

\section{INTRODUCTION}

Streptococcus agalactiae (group B Streptococcus - GBS) is often isolated from the lower gastrointestinal and genital tract of healthy adults. It is also a leading cause of neonatal morbidity and mortality, it is an important etiological agent of severe infectious diseases such as neonatal meningitis, sepsis, those in patients with diabetes mellitus or compromised immune defence and orthopedic device infections [1-3]. Various pathogen and host factors mediate specific host-cell interactions and in- terfere with innate immune clearance mechanisms. GBS has many virulence factors including adhesins like C5a peptidase (ScpB), laminin-binding protein (Lmb), the $\alpha$ and $\beta$-subunits of $\mathrm{C}$ protein (Bca and $\mathrm{Bac}$ ), Rib protein and produces a variety of toxins (invasins) such as $\beta$ hemolysin/cytolysin (cylE), hyaluronidase (hylE) and the CAMP factor (cfb)to promote bacterial entry and survival within host cells $[2,4]$. The GBS capsular polysaccharide (CPS) plays a critical role against effective opsono-phagocytic killing [2,5]. To date, on the basis of the antigenic properties of CPS this species can be classified into 10 different serotypes (Ia, Ib, II-IX) [5, 6]. Plurality studies suggested that the CPS of type III GBS is a major virulence factor of this organism, which significantly appeared to be associated with invasive neonatal disease and almost all meningitis, defined as highly virulent clones such as ST-17 [7-10]. Molecular serotyping of GBS based on the detection of serotype-specific genes of the capsular region has been developing rapidly [11].

This study aims to determine the virulence profile of the circulating Bulgarian clinical isolates of GBS, including the highly virulent serotype III by molecular methods and evaluate the differences among studied isolates from healthy pregnant women and non-pregnant ill persons.

\section{MATERIALS AND METHODS}

\subsection{GBS strains.}

A total of 104 non-duplicate isolates of GBS were obtained from pregnant $(n=15)$ and non-pregnant women $(\mathrm{n}=89)$, living in Sofia, Bulgaria, aged 20 - 59 years during the period of September 2018 toMay2019. The patients were divided into two groups: I. Group - Pregnant women were asymptomatic colonized; while II. Group non-pregnant persons were with clinical manifestations of vaginitis or cystitis. The clinical isolates were acquired from vaginal samples $(n=91)$ and samples of urine $(n=13)$.

The identification of the suspected bacterial isolates was accomplished under routine criteria, using betahemolysis on blood agar, a catalase-negative reaction, a positive CAMP test, a lack of susceptibility to bacitracin and a negative pyrrolidonyl arylamidase test (PYR) for presumptive detection. For determining of Lanceûeld serological groups, a PathoDxtra Strep Grouping Kit 
Thermo Scientiûc (Oxoid, UK) was used. For definitive biochemical identification, we used Crystal GP (Becton Dickinson, Kelberg, Germany) when needed. GBS strains were stored in skim milk at $-70^{\circ} \mathrm{C}$ and were sub-cultivated three times on Columbia agar with $5 \%$ sheep blood (Becton Dickinson, Kelberg, Germany) before the experimental work.

\subsection{Extraction of DNA.}

DNA extraction was performed using a DNA sorb AM nucleic acid extraction kit (AmpliSens, Russia), according to the manufacturer's guidelines. For the purpose of DNA extraction, GBS strains were cultured on Columbia blood agar (Becton Dickinson, Kelberg, Germany) for $24 \mathrm{~h}$ at $35^{\circ} \mathrm{C}$ in an atmosphere with $5 \% \mathrm{CO}_{2}$.

2.3. Polymerase chain reaction (PCR) determination of virulence genes of GBS

All GBS strains were screened by PCR for the presence of important virulence genes, namely $\mathrm{Bca}$ (encoding beta Subunit of the C protein), $c y l(E)$ (encoding cytolozyn-heamolysin), rib (Alp family protein Rib), hyl (B) (encoding hyaluronidase protein), using previously described specific primers [4,5]. PCR cycling conditions and primers sequences were presented in table 1 .

2.4. Real-time PCR determination of highly virulent type III GBS

Detection of the capsular serotype III was carried out by using primers designed to amplify a unique region of the polysaccharide capsular gene cpsI, described previously (13). Reaction mixtures consisted $6.25 \mu \mathrm{l}$ of Universal Master Mix (Applied Biosystems, Darmstadt, Germany) containing an AmpliTaq Gold DNA polymerase, dNUTPs, $\mathrm{MgCl} 2$ and reaction buffer, $100 \mathrm{nM}$ of fluorescence-labeled TaqMan probe, $1 \mu$ l of purified template DNA and using $300 \mathrm{nM}$ of each primer in final volume $25 \mu \mathrm{l}$. DNA was amplified at following conditions: Initial denaturation $95^{\circ} \mathrm{C}$ for $3 \mathrm{~min}$; Denaturation $95^{\circ} \mathrm{C}-30$ sec; Annealing temperature $58^{\circ} \mathrm{C}-40 \mathrm{sec}$; Final elongation $72^{\circ} \mathrm{C}-1 \mathrm{~min}$, using Line-Gene $\mathrm{K}$ machine (Bioer Technology Co., LTD., Bio Flux, Corporation, Tokoy, Japan). All positive samples were confirmed by conventional PCR with expected size of the amplicons 170bp (Tabl. 1).

Table 1. PCR cycling conditions and primers sequences used in the study.

\begin{tabular}{|c|c|c|c|}
\hline Target genes & $\begin{array}{l}\text { Sequence } \\
\left(\text { Forward 5' } \rightarrow 3^{\prime}\right) \text {, } \\
\left(\text { Reverse } 5^{\prime} \rightarrow 3^{\prime}\right)\end{array}$ & $\begin{array}{l}\text { Melting } \\
\text { temperature }\end{array}$ & $\begin{array}{c}\text { Amplicon } \\
\text { Size (bp) }\end{array}$ \\
\hline cylE & $\begin{array}{l}\text { F- TGACATTTACAAGTGACGAAG } \\
\text { R- TTGCCAGGAGGAGAATAGGA }\end{array}$ & $54{ }^{\circ} \mathrm{C}$ & 300 \\
\hline$B c a$ & $\begin{array}{l}\text { F- TAACAGTTATGATACTTCACAGAC } \\
\text { R- ACGACTTTCTTCCGTCCACTTAGG }\end{array}$ & $54{ }^{\circ} \mathrm{C}$ & 535 \\
\hline$R i b$ & $\begin{array}{l}\text { F- CAGATGCCGATAAGA } \\
\text { R- TACGCGGATCGACAA }\end{array}$ & $52{ }^{\circ} \mathrm{C}$ & 237 \\
\hline hylB & $\begin{array}{l}\text { F- CCGTTATCAGTTACAGGTC } \\
\text { R- GTCGATGTAAGAACCGTCAGC }\end{array}$ & $54{ }^{\circ} \mathrm{C}$ & 714 \\
\hline cps $I$ & $\begin{array}{l}\text { F- GGAATTGTTCTTTATTTTTCTGCCT } \\
\text { R- ACTATACCAAAAGTTGAGAATA } \\
\text { ATAATACAATACTCCAATGA }\end{array}$ & $58^{\circ} \mathrm{C}$ & 170 \\
\hline
\end{tabular}

\section{Statistical Analysis}

Differences were analyzed using unpaired Descriptive statistics, Fisher's exact test, SPSS for Windows, Version 19.0 USA, Chicago, SPSS Inc. The significance of results was determined at the level of $\mathrm{p} \leq 0.05$.

\section{RESULTS}

PCR detection of five important virulence genes showed that $c y l E(91.3 \%)$ was the most prevalent one among the total isolates of GBS. Genes encoding the C protein $(b c a)$, hyaluronate lyase $(h y l B)$, Alp family pro- tein Rib ( $r i b)$ were presented in $51 \%, 17.3 \%$ and $22.1 \%$ respectively of the examined isolates, showed in table 2 . By using real-time PCR, we found that $13.5 \%(n=14)$ from all tested Bulgarian GBS strains confirmed as GBS serotype III and harbored cpsI gene. Some of the the real-time PCR results were shown fig.1. The distribution of genetic elements encoding virulence factors among 104 isolates of GBS from two groups patients were presented in Table 2. No significant differences between the two groups were observed excluding the presence of cpsI. 
Fig. 1. Real-time PCR-based detection of serotype III in Bulgarian GBS strains.

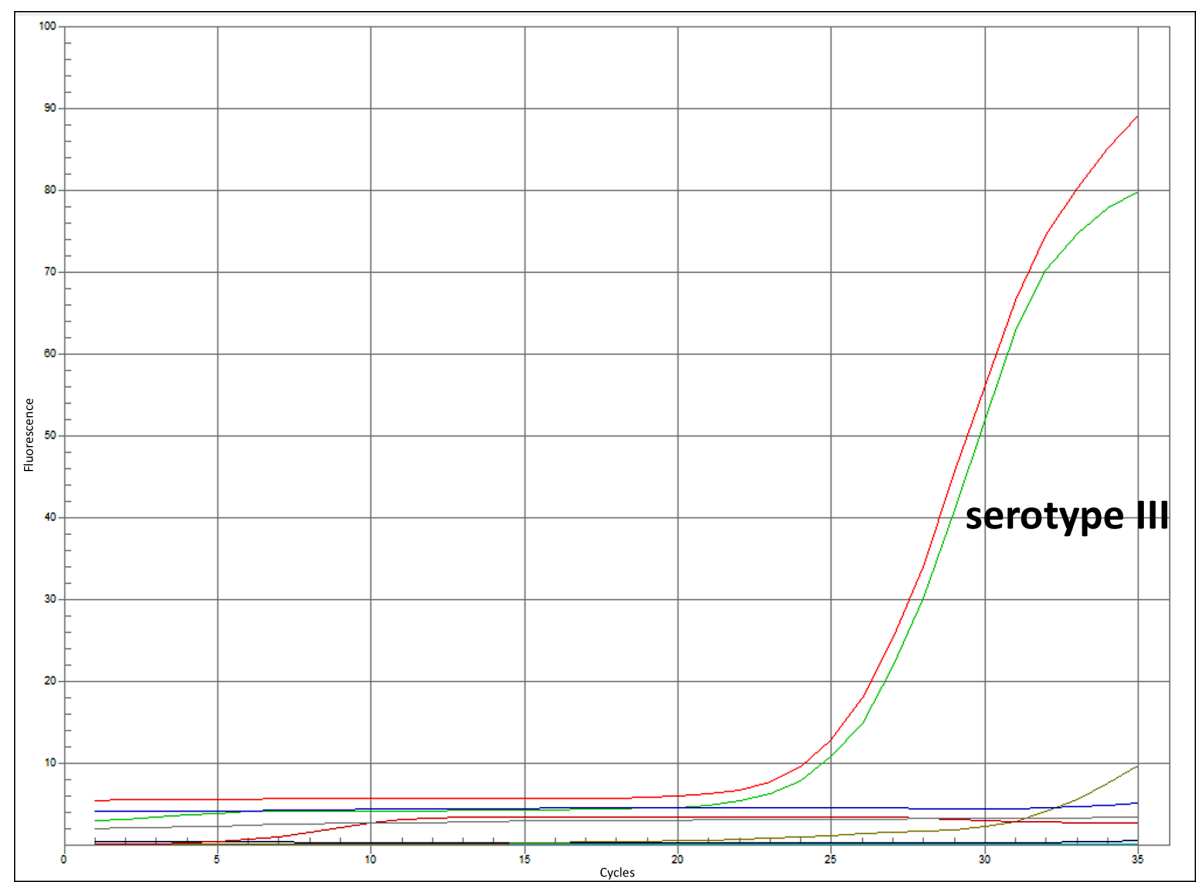

Table 2. Distribution of virulence factors among 104 isolates of GBS from two groups patients.

\begin{tabular}{|c|c|c|c|c|c|c|c|}
\hline & \multicolumn{2}{|c|}{$\begin{array}{l}\text { Non-preganant women } \\
\mathrm{n}=89\end{array}$} & \multicolumn{2}{|c|}{$\begin{array}{l}\text { Pregnant women } \\
n=15\end{array}$} & \multicolumn{2}{|c|}{$\begin{array}{l}\text { Total } \\
\mathrm{n}=104\end{array}$} & \multirow[t]{2}{*}{$P$ value } \\
\hline & $\mathbf{N}$ & $\%$ & $\mathrm{n}$ & $\%$ & $\mathrm{n}$ & $\%$ & \\
\hline cylE & 81 & 91 & 14 & 93.3 & 95 & 91.3 & 1.000 \\
\hline$B c a$ & 46 & 51.7 & 7 & 46.7 & 53 & 51 & 0.7849 \\
\hline Rib & 19 & 21,3 & 4 & 26,7 & 23 & 22,1 & 0.7375 \\
\hline hylB & 16 & 18 & 2 & 13,3 & 18 & 17,3 & 1.000 \\
\hline cpsI & 9 & 10,1 & 5 & 33.3 & 14 & 13,5 & $\underline{0.0291}$ \\
\hline
\end{tabular}

*The underlined text shows a statistically significant difference

\section{DISCUSSION}

GBS can lead the development of the various pathogenic mechanisms due to the fact that it expresses a large number of virulence factors that allow it to suppress the host's immune system. In the present work, the most frequently found virulence factor was $c y l(E)$ in $91.3 \%$. There are some data about this gene encoding GBS $\beta$ haemolysin/cytolysin promotes lung epithelial cell invasion and triggers the release of interleukin-8 (IL-8), a principal neutrophil chemoattractant [2]. Other authors reported that moreover, $\beta$-haemolysin / cytolysin toxin contributes directly to cardiomyocyte dysfunction and apoptosis, which may increase its role in pathophysiological anomalies of GBS sepsis [13]. The gene encoding the alpha antigen, $b c a$, was found in $1 / 2$ of the circulating isolates of GBS in our region. Bca is homologous to the antiphagocytic M-proteins of group A streptococci, and the antigenicity and virulence of GBSstrains containing the alpha antigen is depend on the number of repeats expressed [14]. Our results for the finding if this gene are similar to those from Spain [15], but not in those from China, where $b c a$ is found in only $21 \%$ from studying GBS strains [16]. In our study, hyl $(B)$ and $r i b$ gene were detected in $17.3 \%$, resp. $22.1 \%$ from the examined streptococcal isolates. It is a higher rate for $h y l(B)$ than this one from Spain [17], and low finding for rib in comparing to the reports from Spain, China, Iran [15-17]. The present results showed that $13.5 \%$ of Bulgarian GBS strains belong to the highly virulent serotype III, encoded by $c p s I$, which cause most cases of neonatal meningitis [8-10]. In general many studies report that serotype III GBS is predominant in most part of the world [18, 19]. Compared to an overall serotype III prevalence of $25 \%$, Central America and South-Eastern Asia, as well as some South Asian countries (11\%) had a lower reported prevalence of serotype III [19]. Our study showed that Bulgar- 
ian isolates had a prevalence of GBS serotype III in the group of pregnant women. A recent Serbian report showed that CPS type III predominated in both invasive and noninvasive study groups [20].

The streptococcal isolates from healthy pregnant women of GBS and those from ill non-pregnant ill patients were with no significant difference in the rate of genes in their virulence profile excluding the presence of cpsI, that showed higher frequencies in pregnant ones. In the previous study, other Bulgarian authors showed that earlyonset neonatal GBS infection in $77.3 \%$ of the cases came with clinical symptoms of Maternal-fetal infection [21]. The present results demonstrated that the Bulgarian clini- cal isolates GBS harbored many virulence determinants and especially the finding of cpsI, encoding highly virulent serotype III predominantly in $33.3 \%$ pregnant healthy carriers.

\section{CONCLUSION}

The risk of neonatal and prenatal GBS infection in $1 / 3$ of healthy pregnant women colonized by streptococcal strains with highly virulent capsular serotype in combination with other strong virulent factors was demonstrated by this study. The regular screening for GBS and properly treatment could be reduce the severe maternalfetal infections due to this microorganism.

\section{Acknowledgements}

This work is supported by the Bulgarian Ministry of Education and Science under the National Program for Research "Young Scientists and Postdoctoral Students (AM)" Medical University, Sofia.

\section{REFERENCES:}

1. Seng P, Vernier M, Gay A, Pinelli PO, Legré R, Stein A. Clinical features and outcome of bone and joint infections with streptococcal involvement: 5 -year experience of interregional reference centres in the south of France. New Microbes New Infect. 2016 Apr 13;12:8-17. [PubMed] [Crossref]

2. Maisey H, Doran K, Nizet V. Recent advances in understanding the molecular basis of group B Streptococcus virulence. Expert Rev Mol Med. 2008 Sep 22;10:e27. [PubMed] [Crossref]

3. Moore MR, Schrag SJ, Schuchat A. Effects of Intrapartum Antimicrobial Prophylaxis for Prevention of group-B-streptococcal Disease on the Incidence and Ecology of Early-Onset Neonatal Sepsis. Lancet Infect Dis. 2003 Apr;3(4):201-13. [PubMed] [Crossref]

4. Eskandarian N, Ismail Z, Neela $\mathrm{V}$, van Belkum A, Desa MN, Amin Nordin S. Antimicrobial susceptibility profiles, serotype distribution and virulence determinants among invasive, non-invasive and colonizing Streptococcus agalactiae (group B streptococcus) from Malaysian patients. Eur J Clin Microbiol Infect Dis. 2015 Mar;34(3):579-84. [PubMed] [Crossref]

5. Sendi P, Johansson L, NorrbyTeglund A. Invasive group B Streptococcal disease in non-pregnant adults : a review with emphasis on skin and soft-tissue infections. Infection. 2008
Mar;36(2):100-11.

[Crossref]

6. Slotved H, Kong F, Lambertsen L, Sauer S, Gilbert GL. Serotype IX, a Proposed New Streptococcus agalactiae Serotype. J Clin Microbiol. 2007 Sep;45(9):2929-36. [PubMed] [Crossref]

7. Madzivhandila M, Adrian PV, Cutland CL, Kuwanda L, Schrag SJ, Madhi SA. Serotype distribution and invasive potential of group B streptococcus isolates causing disease in infants and colonizing maternal-newborn dyads. PLoS One. 2011 Mar 21;6(3):e17861. [PubMed] [Crossref]

8. Seifert KN, Adderson EE, Whiting AA, Bohnsack JF, Crowley PJ, Brady LJ. A unique serine-rich repeat protein (Srr-2) and novel surface antigen (epsilon) associated with a virulent lineage of serotype III Streptococcus agalactiae. Microbiology. 2006 Apr;152(Pt 4):1029-40. [PubMed] [Crossref]

9. Lazzarin M, Mu R, Fabbrini M, Ghezzo C, Rinaudo CD, Doran KS, Margarit I. Contribution of pilus type $2 \mathrm{~b}$ to invasive disease caused by a Streptococcus agalactiae ST-17 strain. BMC Microbiol. 2017 Jul 3;17(1): 148. [PubMed] [Crossref]

10. Six A, Bellais S, Bouaboud A, Fouet A, Gabriel C, Tazi A, et al. Srr2, a multifaceted adhesin expressed by ST-17 hypervirulent Group B Streptococcus involved in binding to both fibrinogen and plasminogen. Mol
Microbiol. 2015 Sep;97(6):1209-22. [PubMed] [Crossref]

11. Breeding KM, Ragipani B, Lee KD, Malik M, Randis TM, Ratner AJ. Real-time PCR-based serotyping of Streptococcus agalactiae. Sci Rep. 2016 Dec 2;6: 38523. [PubMed] [Crossref]

12. Creti R, Fabretti F, Orefici G, von Hunolstein C. Multiplex PCR assay for direct identification of group B streptococcal alpha-protein-like protein genes. J Clin Microbiol. 2004 Mar;42(3):1326-9.[PubMed] [Crossref]

13. Hensler ME, Miyamoto S, Nizet V. Group B streptococcal betahemolysin/cytolysin directly impairs cardiomyocyte viability and function. PLoS One. 2008 Jun 18;3(6): e2446. [PubMed] [Crossref]

14. Madoff L, Michel J, Gong E, Kling D, Kasper D. Group B streptococci escape host immunity by deletion of tandem repeat elements of the alpha C protein. Proc Natl Acad Sci U S A. 1996 Apr 30;93(9):4131-6. [PubMed] [Crossref]

15. López Y, Parra E, Cepas V, Sanfeliú I, Juncosa T, Andreu A, et al. Serotype, virulence profile, antimicrobial resistance and macrolide-resistance determinants in Streptococcus agalactiae isolates in pregnant women and neonates in Catalonia, Spain. Enferm Infecc Microbiol Clin. 2018 Oct;36(8):472-477. [PubMed] [Crossref]

16. Nie S, Lu X, Jin Z, Gao J, Ma 
D, Deng J, et al. Characterization of group B Streptococcus isolated from sterile and non-sterile specimens in China. Diagn Microbiol Infect Dis. 2018 Sep;92(1):56-61. [PubMed] [Crossref]

17. Beigverdi R, Jabalameli F, Mirsalehian A, Hantoushzadeh S, Boroumandi S, Taherikalani M, et al. Virulence factors, antimicrobial susceptibility and molecular characterization of Streptococcus agalactiae isolated from pregnant women. Acta Microbiol Immunol Hung. 2014 Dec; 61(4):425-34. [PubMed] [Crossref]
18. Edmond K, Kortsalioudaki C, Scott S, Schrag S, Zaidi A, Cousens S, et al. Group B streptococcal disease in infants aged younger than 3 months: systematic review and metaanalysis. Lancet. 2012 Feb 11;379 (9815):547-56. [PubMed] [Crossref]

19. Russell N, Seale A, O’Driscoll M, O'Sullivan C, Bianchi-Jassir F, Gonzalez-Guarin J, et al. Maternal Colonization With Group B Streptococcus and Serotype Distribution Worldwide: Systematic Review and Meta-analyses. Clin Infect Dis. 2017 Nov 6;65(suppl_2):S100-S111.

\section{[PubMed] [ $\underline{\text { Crossref }}$}

20. Gajic I, Plainvert C, Kekic D, Dmytruk N, Mijac V, Tazi A, et al. Molecular epidemiology of invasive and non-invasive group B Streptococcus circulating in Serbia. Int J Med Microbiol. 2019 Jan;309(1):19-25. [PubMed] [Crossref]

21. Todorova-Christova M, Vacheva R, Decheva A, Nikolov A, Slancheva B, Stoichkova D, et al. A study on earlyonset neonatal group B streptococcal infection, Bulgaria, 2007-2011. Arch Pediatr. 2014 Sep; 21(9):953-60. [PubMed] [Crossref]

Please cite this article as: Muhtarova A, Gergova R, Mitov I. Virulence profile of Bulgarian clinical isolates Streptococcus agalactiae- PCR determination. J of IMAB. 2020 Apr-Jun;26(2):3203-3207.

DOI: https://doi.org/10.5272/jimab.2020262.3203

Received: 01/08/2019; Published online: 22/06/2020

Address for correspondence:

Adile Muhtarova

Department of Medical Microbiology, Faculty of Medicine, Medical University of Sofia

2, Zdrave Str., 1431 Sofia, Bulgaria.

E-mail: adimuhtarova@gmail.com, 